\title{
The Effect of Marketing Communication and Relationship Marketing to Business Success (Study on Consumer UD.Mitra Phillips Seafood Indonesia in Tampo)
}

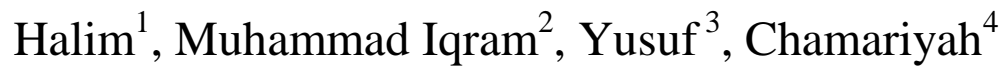 \\ Faculty of Economics and Business, University of Halu Oleo, Kendari, Indonesia \\ Faculty Of Economy, University of Wijaya Putra, Surabaya, Indonesia
}

\begin{abstract}
This study aimed to determine the effect of Marketing Communication and Relationship Marketing to business success. This study was conducted to collect questionnaire data from 45 respondents consumers UD. Phillips Seafood Indonesia partners in Tampo with data processing techniques using multiple linear regression method. The results showed that the Marketing Communication and Relationship Marketing positive and significant impact on the success of the business.
\end{abstract}

Keywords: Marketing Communication, Relationship Marketing, Business Success.

\section{Introduction}

In the era of globalization and the entry of the ASEAN economic community in Indonesia, as well as development and growth of today's global economy. Sue many companies to look back on the company's strategy that they employ to be able to compete and maintain its existence. Companies should be able to apply the right strategy, is to attempt to satisfy the needs and desires of consumers, so that Business Success can be achieved.

Various marketing strategies applied in order to achieve Business Success.The marketing strategy which is conducted by company, such as by creating long-term relationships with customers through Relationship Marketing and introduce products through Marketing Communication.The good Marketing Communication and the good Relationship Marketing to customers has been recognized as the dominant factor that influencing Business Success today. Marketing Communication can instill in the minds of consumers regarding the product information that will be sold and Relationship Marketing that can create long-term relationships with company partners and that's certainly very profitable for the company.

Several previous studies have claimed that,Marketing Communicationcan ensure the survival and create Business Success for the company (Chiang et al, 2002; Janet, 2008; Maselli, 2002; Moses, 2011; Mosley and Matchett, 1999; Roger and Kirstina, 2011; Sujanet al, 2010). But, not all of the researchers said the same thing, plenty of research says if Marketing Communication can't create the Business Success.(Aleksandra, 2014; Anthony et al, 2003;Janet, 2005; Zich, 2012).

Beside from Marketing Communication, Relationship Marketing also plays an important role in the Business Success of companies (Ehigie et al, 2009). Several previous studies have claimed that, thecompanies that implement Relationship Marketing to consumers can create a Business Success (Arun et al, 1999; Bergeron, 2001; Robert, 1994; Soca, 2014).But, on the other hand, there are some research says that Relationship Marketing can't create the Business Success (Arunet al, 1999; Ken and Tim, 1999; Nguyen and Simkin, 2013; Priluck, 2003; Ramkumar, 2007; Rosenfield, 1999). Based on literature and empirical study, the author found the gap between the effectof Marketing Communication and Relationship Marketing to Business Success, so this is an interesting phenomenon and important to beexamined again.

\subsection{Basic Concept of Marketing Communication}

\section{Literature Review}

Marketing Communication is an important aspect in the overall marketing mission as well as the determinants of successful marketing (Shimp, 2003: 4). Marketing Communication can be understood by describing the two constituents, namely Communication and Marketing. Communication is the process in which thinking and understanding between the submitted individuals or organizations and individuals (Shimp, 2003: 4). While Marketing according to Kotler is a social and managerial process that makes individuals and groups obtain what they need and want, through creating and reciprocal exchange of products and value with other people (Widjajanta and Widyaningsih, 2007: 62)

\subsection{Indicators of Marketing Communication}

There are several indicators of Marketing Communication, one of which was said by Kotler and Keller (2005: 249): 
a) Advertising: Forms of indirect communication is based on information about the advantages or benefits of the product.

b) Sales Promotion: Forms of persuasion directly through the use of various incentive.

c) Direct Marketing: Interactive Marketing and utilize one or several media.

d) Personal Sales: Direct communication (face to face) between sellers andpotential buyer

\subsection{Basic Concepts of Relationship Marketing}

Relationship Marketing is an approach that emphasized on businesses attract and retain customers through an increase in the company's relationship with customers. Kotler \& Armstrong (2001: 304) describes the Relationship Marketing is an effort to create, maintain and enhance a strong relationship with customers and other stakeholders. Morgan \& Hunt (Bennett et al, 2000) also define Relationship Marketing as an all marketing activities directed to establish, develop and maintain relational exchanges with customers, thus creating success.

\subsection{Indicators of Relationship Marketing}

According toSivesan (2012) there are three indicators that affect Relationship Marketing:

a) Trust: A willingness to rely on the ability, integrity and motivation of others to act in order to satisfy the needs and interests. (Sheth and Mittal, 2004).

b) Commitment: Desire or a strong desire to maintain and continue relationships that considered important and long-term value. (Sheth and Mittal, 2004).

c) Handling Conflict: the company's ability to prevent or minimize the impact of potential things that could lead to conflict. (Ball et al, 2004).

\subsection{Business Success}

Business Success is the ultimate goal of a company, in which all the activities in it is intended to achieve a Business Success (Kotler, 2000: 16). Business Success can be seen from how well the company to make customers be more satisfied with the products sold by the company. According to Kotler customercentered company, customer satisfaction is the goal and a major factor in Business Success of a company (Kotler, 2000: 16).

\subsection{Indicators of Business Success}

According to Kotler (2000: 16) explains that the indicators of Business Success can be seen on: Customer Satisfaction.

Consumer satisfaction is the extent to which the benefits of a product is perceived in accordance with what is expected of customers (Taufiq, 2005: 41). Kotler (2000: 20) says that customer satisfaction is the level of one's feelings after comparing the performance of the product that he felt with his expectations.

\subsection{The Framework Research Concept}

Business Success in a company can be created because existence of the proper Marketing Communication and the good Relationship Marketing to partners Marketing Communication can be realized through the use of tools Marketing Communication, among others are Sales Promotion, Direct Marketing, Personal Sales (Kotler andKeller, 2005: 249).Besides from Marketing Communication, Relationship Marketing can also be done in building long-term relationships for the company, this can be realized through "Trust, Commitment, Handling Conflict" (Sivesan, 2012). With the proper implementation ofthe Marketing Communication in selling products and establish a good relationship through the Relationship Marketing then the Business Success in terms of "Customer Satisfaction" (Kotler, 2000: 16) will be realized.

\subsection{Hypothesis}

Based on the discussion and its relation with the title of the research, then the formulation of hypotheses that can be made are as follows:

$\mathrm{H} 1=$ There is a positive and significant effect between Marketing Communication and Relationship Marketing to Business Success on UD Mitra Phillips Seafood Indonesia.

$\mathrm{H} 2=$ There is a positive and significant effect between Marketing Communication to Business Success onUD Mitra Phillips Seafood Indonesia.

H3 = There is a positive and significant effect between Relationship Marketing to Business Success onUD Mitra Phillips Seafood Indonesia.

\section{Research Methods}

This research is classified as descriptive research, which only measure variables that exist and do not manipulate these variables. Total sample of 45 withthe population of all consumers UD.Mitra Phillips Seafood Indonesia in Tampo. The sampling technique used in this study is Accidental Sampling, data retrieval by questionnaire and data analysis technique used is multiple linear regression method. 


\subsection{Results}

\section{Results And Discussion}

\subsubsection{Regression Test Results}

Calculation of multiple linear regression analysis in this study using a computer with the help of SPSS software.

(Statistical Package for Social Sciences). The calculation results can be seen in the following table:

Results of Multiple Linear Regression Analysis

\begin{tabular}{|c|c|c|c|}
\hline Independent Variables & Regression Coefficients & $t_{\text {count }}$ & Sig. \\
\hline Marketing Communication & 0.291 & 2.453 & 0.018 \\
\hline Relationship Marketing & 0.334 & 3.225 & 0.002 \\
\hline Constant & \multicolumn{2}{|l|}{ 1.564 With Sig 0.280} & \multirow{6}{*}{$\begin{array}{l}\mathrm{N}=45 \\
\quad \propto=0.05\end{array}$} \\
\hline R Square & \multicolumn{2}{|l|}{0.775} & \\
\hline R & \multicolumn{2}{|l|}{0.880} & \\
\hline $\boldsymbol{F}_{\text {count }}$ & \multicolumn{2}{|l|}{72.214} & \\
\hline F Sig & \multicolumn{2}{|l|}{0.000} & \\
\hline Std. Error & \multicolumn{2}{|l|}{1.043} & \\
\hline
\end{tabular}

Based on the results ofSPSS output, thenthe results obtained regression equation for Marketing Communication and Relationship Marketing to Business Success as follows:

$\mathrm{Y}=1.564+0.291 X_{1}+0.334 X_{2}$

Explanation of the equation are as follows:

1. Constant 1.564,meaning thatif Marketing Communication and Relationship Marketing is 0, then Business Success in value 1.564 .

2. The regression coefficient for Marketing Communication is 0.291,meaning that if Marketing Communicationincreases one of unit, then Business Success will be increased by 0.291 units, assuming the other independent variables remain valuable.

3. The regression coefficient for Relationship Marketing is 0.334 , meaning that ifRelationship Marketingincreases oneof unit, then Business Success will be increased by 0.334 units, assuming the other independent variables remain valuable.

\subsubsection{Analysis The coefficient of determination (Adjusted $\boldsymbol{R}^{2}$ )}

Based on the results of SPSS output, R Square figures obtained by 0.775 or $(77.5 \%)$. This shows that the percentage contribution of the effect of the independent variables, namely Marketing Communication and Relationship Marketing to Business Success by $77.5 \%$ or variations of the independent variables used in the model is able to explain $77.5 \%$ of the variation of the dependent variable. While the rest influenced by other variables not included in this research model.

\subsection{3 t-Test}

t-tests were used to determine whether the independent variable partial effect on the dependent variable. To know the t-test, $t_{\text {count }}$ value compared with the $t_{\text {table }}$ value. With the testing criteria as follows:

a. Ho is accepted if $t_{\text {table }}<t_{\text {count }}$

b. Ho isrejected if $t_{\text {count }}>t_{\text {table }}$

\section{A. Marketing Communication to Business Success}

Based on the results of SPSS output, obtained $t_{\text {count }} 2.453$ while $t_{\text {table }}$ is sought on $\alpha=5 \%: 2=2.5 \%$ (Test 2 sides) with degrees of freedom (df) $n-k-1$ or $45-2-1=42$ ( $n$ is the number of data and $k$ is the number of independent variables), by testing two sides (significance $=0.025$ ) the results obtained for $t_{\text {table }}$ of 2.018 , so it can be concluded that $t_{\text {count }}>t_{\text {table }}$.

Based on these data, the value $t_{\text {count }}>t_{\text {table }}(2.453>2.018)$, then Ho is rejected, meaning that the Marketing Communication partially effect to Business Success. $t_{\text {count }}$ value positive meaning thatthe effect ofthat occurs is positive or can be interpreted the higher or better Marketing Communication then Business Success will increase.

\section{B. Relationship Marketing to Business Success}

Based on the results of SPSS output, obtained $t_{\text {count }} 3.225$ while $t_{\text {table }}$ is sought on $\propto=5 \%: 2=2.5 \%$ (Test 2 sides) with degrees of freedom (df) $n-k-1$ or $45-2-1=42$ ( $n$ is the number of data and $k$ is the number of independent variables), by testing two sides (significance $=0.025$ ) the results obtained for $t_{\text {table }}$ is 2,018 , so it can be concluded that $t_{\text {count }}>t_{\text {table }}$. 
Based on these data, the value $t_{\text {count }}>t_{\text {table }}(3.225>2.018)$, then Ho is rejected, meaning that the Relationship Marketing partially effect to Business Success. $t_{\text {count }}$ value positive meaning thatthe effect ofthat occurs is positive or can be interpreted the higher or better Relationship Marketing then Business Success will increase.

\subsubsection{F-Test}

F-test was used to test whether the independent variables simultaneously affect on the dependent variable To know the F-test, $F_{\text {count }}$ value compared with the $F_{\text {table }}$ value. With the testing criteria as follows:

a. Ho is accepted if $F_{\text {count }}<F_{\text {table }}$

b. Ho is rejected if $F_{\text {count }}>F_{\text {table }}$

Based on the results of SPSS output, obtained $F_{\text {count }} 72.214$ while $F_{\text {table }}$ issought by the degree of confidence $95 \%, \propto=5 \%$, df $1=2$ (the number of independent variables) and df 2 (n-k-1) or 45-2-1 $=42$ (n is the number of data and $\mathrm{k}$ is the number of independent variables). Results obtained $F_{\text {table }}$ of 3.220 , so it can be concluded that $F_{\text {count }}>F_{\text {table }}$.

Based on these data, the value $F_{\text {count }}>F_{\text {table }}(72.214>3.220)$ then Ho is rejected, meaning that the Marketing Communication and Relationship Marketing simultaneously affect to Business Success.

\section{Discussion}

4.2.1 Effect of VariableMarketing Communication and Relationship MarketingSimultaneously Affect to Business Success

Based on the results of the study, showed that the variables of Marketing Communication and Relationship Marketing to Business Success has a simultaneous effect, meaning that the Business Success of a company is affected by the Marketing Communication and Relationship Marketing good from the company.

The analysis also showed that the overall variable Marketing Communication and Relationship Marketing has a significant positive effect on Business Success, which can be interpreted better Marketing Communication and Relationship Marketing a company will increase the Business Success.

The results are consistent with research conducted by Chiang et al, 2002; Janet, 2008; Maselli, 2002; Moses, 2011; Mosley and Matchett, 1999; Roger and Kirstina, 2011; Sujanet al, 2010 which states that Marketing Communication can ensure the survival and create Business Success for the company, as well as research conducted by Arunet al, 1999; Bergeron, 2001; Robert, 1994; Soca, 2014 stating that the company is applying Relationship Marketing to customers can create a Business Success.

\subsubsection{Effect of Variable Marketing Communication Partial to Business Success}

The results showed that the Marketing Communicationpositively and significantly to Business Success. This shows that the Marketing Communication has a good effect in improvement of Business Success.

The role of Marketing Communication in a company is important because it will affect the company's Business Success. Marketing Communication plays a very important for the company because without marketing communication, consumers and society as a whole will not know the existence of products on the market.

The results of this study are consistent with the theory put forward by Mosley and Matchett (1999) which explains that the marketing communication plays an important role in the survival and company's Business Success.

\subsubsection{Effect of Variable Relationship Marketing Partial to Business Success}

The results showed that the Relationship Marketing positively and significantly to Business Success. This shows that the Relationship Marketing has a good effect in improvement of Business Success.

Relationship Marketing to Business Success means withdrawing, development and maintenance of relationships with consumers and placing them in the center of attention as an individual. In this way, Relationship Marketing leads to the creation of stable partnership between consumers and providers, beneficial for both parties to personalize relationship between parts and for beneficial results in terms of Business Success of the company.

The results of this study are consistent with the theory put forward by Soca (2014), which explains that the Relationship Marketing is one important factor in achieving Business Success.

\section{Conclusion}

Based on the analysis of data and discussion shows that the Marketing Communication and Relationship Marketing has a significant and positive effecttoBusiness Success either simultaneously or partially. These results show that the better Marketing Communication and Relationship Marketing applied by the company will increase the Business Success. 


\section{References}

[1]. Aleksandra, Kaniewska. 2014. Negative Effects of Personalization in Direct Marketing. International Journal of Arts \& Sciences, vol. 07(02), pp. 89-98.

[2]. Anthony et al. 2003. Communication of Risks and Side Effects in Prescription Medicine Advertising. Conference Proceedings Adelaide, pp. 83-89.4

[3]. Arunet al. 1999. Antecedents and Consequences of Relationship Marketing. Industrial Marketing Management, vol. 28, pp. 601611 .

[4]. Bennett, et al. 2000. Trust, Commitment and Attitudinal Brand Loyalty : Key Constructs in Business-To-Business Relationships. ANZMAC 2000 Visionary Marketing for the 21st Century: Facing the Challenge.

[5]. Bergeron, Kathleen A. 2001. Relationship Marketing : A Key To Success and Survival. Public Road, vol. 65, no. 1.

[6]. Chiang et al. 2002. Direct Marketing, Indirect Profits: A Strategic Analysis of Dual-Channel Supply-Chain Design. Management science, vol. 00, no. 00, pp. 1-20.

[7]. Ehigie, et al. 2009. Managing Students' Loyalty to School After Graduation Through Relationship Marketing. The TQM Journal, vol. 21 no. 5, 2009 pp. 502-516.

[8]. Janet, Bob. 2008. Four Strategies to Increase Sales and Profit. Dealerscope, vol. 50, no. 4, Technology Collection pg. 26.

[9]. Janet, Hoek,. 2005. Marketing Communications and Obesity: A View From The Dark Side. The New Zealand Medical Journal, vol. 118 , no. 1220 , ISSN. $1175-8716$.

[10]. Ken and Tim. 1999. The Dark Side of Long-term Relationship in Marketing Service. Journal of marketing research, pp. 132-141.

[11]. Kotler, Philip danAmstrong, Gary. 2001. Prinsip-prinsipPemasaran (Principles of Marketing), Edisi Bahasa Indonesia, Jilid I. Penerbit Erlangga : Jakarta.

[12]. Kotler, Philip. 2000. Marketing Management, Millenium Edition. Pearson Custom Publishin : United States of America.

[13]. Kotler, Philip. 2005. ManajamenPemasaran, Jilid 1 dan 2. PT. IndeksKelompok Gramedia : Jakarta.

[14]. Maselli, Jennifer. 2002. Better Communication Leads to More Sales. Information Week, vol. 889, pg. 32.

[15]. Moses, Jhon. 2011. Benefits Communication Is So 1980s : Market Your Benefits and Thrive!. John Benefits Quarterly, vol. 27, no. 2, Research Library pg. 28.

[16]. Mosley and Matchett. 1999. Marketing Communication Strategies for Y2K Survival. Marketing Management, vol. 8, no. 3, Research Library pg. 4.

[17]. Nguyen and Simkin, 2013. The dark side of CRM: Advantaged and Disadvantaged Customers. Journal of Consumer Marketing, vol. 30(1), pp. 17-30.

[18]. Priluck, Randi. 2003. Relationship Marketing Can Mitigate Product and Service Failures. The Journal of Service Marketing, vol. 17, no. 1.

[19]. Ramkumar. 2007. The Dark Side of Relationship Marketing. International Marketing Conference on Marketing \& Society, 8-10 April, IIMK.

[20]. Robert, Stacey. 1994. How Not to Do Relationship Marketing. Journal of Direct Marketing, vol. 56, no. 10, Research Library pg. 67.

[21]. Roger and Kirstina. 2011. The Earnings Effects Of Marketing Communication Expenditures During Recessions. Journal of Advertising, vol. 40, no. 2, pp. 5-24.

[22]. Rosenfield, James. 1999. Whatever Happened to Relationship Marketing? Nine Big Mistakes. Journal of Direct Marketing, vol. 62, no 1.

[23]. Sheth, Jagdish and Mittal, Banwari. 2004. Customer Behaviour : Managerial Perspective, Second Edition. Thomson : Singapore.

[24]. Shimp, Terence. 2003. PeriklanandanPromosi. Erlangga: Jakarta.

[25]. Sivesan. 2012. Impact of relationship marketing on customer value creation in mobile service providers Sri Lankan experience. Herald Journal of Marketing and Business Management, vol. 1 (1), pp. 016 - 021.

[26]. Soca, Diana. 2014. Relationship Marketing : The Key of The Success in Business. Romanian Economic and Business Review, vol. 6, no. 1 .

[27]. Sujanet al. 2010. Increasing Sales Productivity By Getting Salespeople to Work Smarter. Journal of Personal Selling \& Sales Management, pp. 9-19.

[28]. Taufiq Amir. 2005.DinamikaPemasaran :Jelajahi\&Rasakan. PT. Raja GrafindoPersada : Jakarta.

[29]. WidjajantadanWidyaningsih. 2007. MengasahKemampuanEkonomi. IKAPI : Bandung.

[30]. Zich, Frantisek. 2012. On the Theme of Marketing Communication Side Effects. Journal of Communication, vol. 100, no. 10. 